\title{
Canavalia Ensiformis (L): In the Contribution of Organic Carbon to Eutric Differentiated Soils
}

\author{
Osmara Renté Martí ${ }^{1}$, Fernando Guridi Izquierdo ${ }^{2}$, Pablo Domingo Pablos Reyes ${ }^{3}$, \\ Yeline Corrales Vila ${ }^{4}$, María Caridad Nápoles García ${ }^{5}$ \\ ${ }^{1}$ Agronomy Department, School of Chemical Engineering and Agronomy, University of Oriente, Santiago de Cuba, Cuba \\ ${ }^{2}$ Chemistry Department, School of Agronomy, Agrarian University of Havana, San José de las Lajas, Cuba \\ ${ }^{3}$ Territorial Station of Sugar Cane Research, Santiago de Cuba, Cuba \\ ${ }^{4}$ Territorial Station of Sugar Cane Research, Palma Soriano, Santiago de Cuba, Cuba \\ ${ }^{5}$ Physiology and Biochemistry Department, National Institute for Agricultural Sciences, Mayabeque, Cuba

\section{Email address:} \\ osmara@uo.edu.cu (O. R. Martí), fguridi@unah.edu.cu (F. G. Izquierdo), pablopablos1968@gmail.com (P. D. P. Reyes), \\ tere@inca.edu.cu (M. C. N. García)
}

\section{To cite this article:}

Osmara Renté Martí, Fernando Guridi Izquierdo, Pablo Domingo Pablos Reyes, Yeline Corrales Vila, María Caridad Nápoles García. Canavalia Ensiformis (L): In the Contribution of Organic Carbon to Eutric Differentiated Soils. American Journal of Applied Scientific Research. Vol. 5, No. 2, 2019, pp. 41-46. doi: 10.11648/j.ajasr.20190502.12

Received: March 19, 2019; Accepted: April 17, 2019; Published: September 10, 2019

\begin{abstract}
The Soil Organic carbon (COS) is part of the organic matter which influences its properties. Currently, the topic is being researched. Therefore, the reserves in relation to the different vegetal coverings in the soils are studied. The objective of the study is to evaluate the changes in the (COS) with different managements of Canavalia ensiformis as green manure/crop coverage (AV/CC) at the Orchard Santiago 2 basic unit of production (UBPC). The production of fresh and dry biomass, the contribution of carbon from the biomass to the soil, the reserves of organic carbon $\mathrm{CO}$, the total organic carbon as well as the organic carbon present in the humic substances were analyzed. The results showed a positive effect on the different Canavalia managements by increasing COS reserves in each treatment. A better response to treatments with incorporative and permanent Canavalia coverage in relation to the control in its initial state in the soil was also observed.
\end{abstract}

Keywords: Organic Carbon, Kidnapping of Carbon, Humic Fraction

\section{Introduction}

Organic $\mathrm{C}$ has the function of being a nutrient source, increases cation exchange capacity (CIC), promotes soil aggregation, besides being a source of energy for microorganisms, is a temperature regulator and acts as Buffer regulating the abrupt changes of $\mathrm{pH}$ [1-3]. In the light of these times, existing research [4] does not rule out investigating the dynamics of organic carbon (CO) in soils as it establishes gains and losses associated with vegetation disturbances and management practices. In the light of these times, existing research [4] does not rule out investigating the dynamics of organic carbon (CO) in soils as it establishes gains and losses associated with vegetation disturbances and management practices.

The Canavalia ensiformis, is one of the most used legumes as a green manure for the contribution it makes to the improvement of soil properties. Today, the use of green manures is advocated for obtaining income in organic matter and for improving soil physical and chemical conditions with sustainability. Some studies [5] of different legumes make known that they increase the CO of the soil; Other authors [6] refer to the use of legumes to take advantage of them in producing phytomass; And also to be used as a function of the sequestration of carbon, in the improvement of the content of the organic matter and the structure of the soil [7]; and others consider that the Canavalia ensiformis (AV/CC) improves the physical properties (quantitative and qualitative) of the soil, mainly if it is incorporated, or is maintained permanently in the soil [8].

Specifically, the carbon content in organic matter varies from 40 to $58 \%$; however, in humic substances they 
comprise 60 to $80 \%$ of the MOS [9]. Humic substances (humic acids, fulvic acids and humins), given their composition, prevent the soil from compacting, transport nutrients from the soil to the plant, retain water, stimulate the proliferation of the microflora; Its main function is to complex and remove metals, as well as substances (chemical and organic) of anthropogenic origin, as well as water contaminants [10].

In very few works consider these humic substances $(\mathrm{SH})$ as a continuous process of transformation of various forms of carbon (C) in the environment, which go through a state of relative equilibrium for a while [11]. These substances contain an abundance of phenolic and carboxylic groups with different molecular weights, being necessary for agricultural production and for the maintenance of environmental functions [12].

The soil under study contributes to the agricultural development of the region; its areas with low content of organic matter among other problems are associated with the application of inadequate management practices among other causes; which limits the use of the soil and its production. This work I consider essential, to evaluate the impact of the use of the legume Canavalia ensiformis in the increase of the organic carbon of the soil.

\section{Materials and Methods}

\subsection{Experimental Procedure}

The trial carried out in areas of the Huerto Santiago 2 basic unit of production (UBPC), in a municipality of Santiago de Cuba on June 2014/2015, in Fluvisol Differentiated soil [13]. Canavalia ensiformis (L) was established as a rainfed cover crop. A random block was used, with four treatments and four replications. Canavalia ensiformis (L) was established as a rainfed cover crop. A random block was used, with four treatments and four replications. Treatment I (Cn): absolute control, coverage and natural soil fertility. Treatment II (CCs / i): The Canavalia coverage in the soil was established until 80 days, the biomass was cut, chopped and exposed on the ground for 72 hours. Treatment III (CC / i): the Canavalia coverage at 80 days was cut, fractioned, exposed on the ground for 72 hours and subsequently incorporated into the soil. Treatment IV (CC / p): the coverage of the legume was maintained permanently for 120 days (the growth of the plant is not interrupted). Plots were established with a total area of $30 \mathrm{~m}^{2}$, and sowing at $0,75 \mathrm{~m}$ between rows and $0,25 \mathrm{~m}$ between plants.

Samples were evaluated on the soil, one at 0 days (before planting) and another at 120 days (after the treatments were established); samples of 10-15 g were taken in each stitch in the sample collection, composed of 30 subsamples; at the depth of $0-20 \mathrm{~cm}$; with an agrochemical auger, selected diagonally (English flag).

Evaluations carried out

Contribution of biomass production and carbon from biomass to soil.
The production of the legume in biomass (fresh and dry) was determined at 80 days; five complete plants were taken at random within the calculation area. Samples of selected plants (leaves, stems and roots; (g / plant) were weighed and left in the oven for $72{ }^{\circ} \mathrm{C}$ until a constant weight was obtained, then weighed again and expressed in $\mathrm{tha}^{-1}$.

Then the contribution of $\mathrm{C}$ of Canavalia biomass was obtained, as described in the previous paragraph; the stock or storage of $\left(\mathrm{C}_{\mathrm{BIOMASA}}\right)$ of the plant is estimated by the method proposed by [14], for herbaceous species. The average carbon fixed was converted into tons and multiplied by the absolute density of the species, and generated carbon accumulation $\mathrm{C} / \mathrm{ha}$ according to the formula: $\mathrm{CA}=\mathrm{dae} * \mathrm{Ct}$. Being: CA: carbon accumulated by the species in ( $\mathrm{t} \mathrm{C}$ ha-1); dae: absolute density of the species in plants per ha; $\mathrm{Ct}$ : average carbon fixed at $\mathrm{t} C$ per plants.

The ratio and / or conversion of Biomass $-\mathrm{C}-\mathrm{CO}_{2}$ was then estimated, by reason of the equivalence in $\mathrm{tCO}_{2}$ by two ways:

(1) $1 \mathrm{TC}$ is equivalent to $3.67 \mathrm{t}$ of $\mathrm{CO}_{2}$ obtained as a function of the molecular weights of $\mathrm{C}$ and $\mathrm{CO}_{2}$, where $1 \mathrm{t}$ biomass $+/-0,5 \mathrm{TC}$ [15] and the formula:

(2) $\mathrm{CO}_{2}$ equi $=\mathrm{CA} * 44$ moles $\mathrm{CO}_{2} / 12$ moles $\mathrm{C}$.

Being $\mathrm{CO}_{2}$ equi: tons per hectare of $\mathrm{CO}_{2}\left(\mathrm{tha}^{-1} \mathrm{CO}_{2}\right)$. CA: carbon accumulated by the species [14].

\subsection{Determination of COS Content}

The content of COS (\%) was determined at the beginning ( 0 days) and at 120 days by the analytical method [16]. From the CO content obtained, the total organic carbon (TOC) content was estimated and / or determined in the samples, according to the proposed equation [3]:

$\mathrm{COT}=\mathrm{CO} * \mathrm{Da} * \mathrm{P} * 10$,

Where: COT: Total organic carbon in soil per surface (Mgha-1); CO: Total organic carbon (\%); Da: Apparent density $\left(\mathrm{Mgm}^{-3}\right)$; P: Depth of the soil (m).

\subsection{Determination of Organic Carbon Content Present in Humic Substances}

The analysis of the organic carbon content in the humic fraction of the soil was determined according to [16]. This method oxidizes the organic $\mathrm{C}$ of the soil by means of the solution of potassium dichromate $\left(\mathrm{K}_{2} \mathrm{Cr}_{2} \mathrm{O}_{4}\right)$ and mixes with concentrated sulfuric acid $\left(\mathrm{H}_{2} \mathrm{SO}_{4}\right)$ to $96-98 \%$, is based on the differences of solubilities of the humic substances of acids and bases. As a result, extractable or extractable $\mathrm{CO}$ was obtained in the fraction and organic soil carbon (COS), humic acid (AH), and fulvic acid (AF) were determined [17]. Then we proceeded to read the absorbance together with a glucose pattern in the Spectrophotometer Genesis 10S UVVIS.

\subsection{Statistical Analysis}

The results obtained in the evaluated years did not differ, they were processed in correspondence to the year 2014. For this, the statistical analysis was carried out with the 
Statgraphics plus version 5.1 package.

\section{Results and Discussion}

\subsection{Effects of Canavalia on the Production of Biomass and on Carbon from Biomass to Soil}

Contributions were made in the production of total fresh biomass of $31,72 \mathrm{t} \mathrm{ha}^{-1}$, of them 17,43 of leaf, 11,79 of stem and 2.5 of root, with the dry biomass obtained $6,6 \mathrm{t}$ ha one. The fresh biomass obtained is in the range reported [18] in Cuba, where the Canavalia contributions ranged between 10 $67 \mathrm{t} \mathrm{ha}^{-1}$ of fresh biomass. In the study, Canavalia's contributions in fresh and dry biomass were remarkable and significant considering the conditions of the soil and the region.

The results obtained prove that the estimate of the stock or warehouse of $\mathrm{C}_{\mathrm{BIOMASA}}$ of Canavalia for the conditions under study reported values of $3,4 \mathrm{t} \mathrm{C} \mathrm{ha-1} \mathrm{of} \mathrm{total} \mathrm{dry} \mathrm{biomass}$ (BS); distributed in 1,75 t $\mathrm{C} \mathrm{ha}^{-1}$ in leaves; 1,33 in stems and $0,32 \mathrm{t} \mathrm{C} \mathrm{ha}^{-1}$ in roots. As a consequence of the contribution of $\mathrm{C}_{\mathrm{BIOMASA}}$ subsequently, the estimated Biomass $-\mathrm{C}-\mathrm{CO}_{2}$ ratio is obtained; these results are framed by normal adsorption rates in the tropics.

Table 1. Estimation of the stock or storage of $\mathrm{C}$ in the Canavalia biomass and the Biomass-C-CO

\begin{tabular}{lcccl}
\hline $\mathbf{C}_{\text {Biomasa }}\left(\mathrm{t} \mathrm{C} \mathrm{ha}^{-1}\right)$ & & & & Biomasa $-\mathbf{C}-\mathbf{C O}_{2}$ \\
\hline Hoja & Tallo & Raíz & Total & \\
\hline$(\%)$ & & & & $\left(\mathrm{tO}_{2} \mathrm{ha}^{-1}\right)$ \\
51,5 & 39,1 & 9,4 & 100 & 24,98 \\
\hline
\end{tabular}

$\mathrm{C}_{\text {BIomasa }}\left(\mathrm{t} \mathrm{C} \mathrm{ha}^{-1}\right)$ : contribution of $\mathrm{C}$ for biomass; Biomass - $\mathrm{C}-\mathrm{CO} 2$ (t CO2 $\left.\mathrm{ha}^{-1}\right)$ : carbon retained in the soil; according to [14] and [15].

Values similar to the estimate of $\mathrm{C}$ obtained in the dry biomass, were studied by other authors in herbaceous plants finding values between 50,9\% [18] and in Canavalia 50,1\% [19].

The obtained result supposes a capture of $\mathrm{CO}_{2}$ of the atmosphere on the part of the plant, this contribution of $\mathrm{C}_{\mathrm{BIOMASA}}$ is later reintegrated or returned to the soil; then, a contribution between soil - plant as a warehouse is established; this conversion and transformation process also shows effective changes in the soil (physical, chemical and biological).

However, these results depend on the type of species, coverage, place, production system and soil among others. Undoubtedly, coverage with rapid growth and development admits to fix a greater amount of $\mathrm{C}$ in the process of photosynthesis. In this regard, it is considered possible that the [20] permanent vegetation cover fulfill the role of $\mathrm{C}$ sinks. Other authors [21] refer to the effect of the AV / CC on greenhouse gases (GHG), the mitigation of change climate; and they emphasize in preliminary studies that when green fertilizers (AV) are incorporated and managed as vegetable cover, given their low $\mathrm{C} / \mathrm{N}$ ratio, they are capable of stimulating the decomposition of $\mathrm{OM}$ and therefore of $\mathrm{C}$ $\mathrm{CO}_{2}$.

\subsection{Effect of Canavalia Ensiformis on the Increase of the Organic C of the Soil}

In Figure 1, there are discrete increases in the levels of organic carbon (CO) and total organic carbon (TOC) in the soil with differences between treatments. The results reveal that the contribution of carbon estimated in the biomass and determined initially (Table1) affects the content or subsequent gain of the element in the soil (Figure 1).
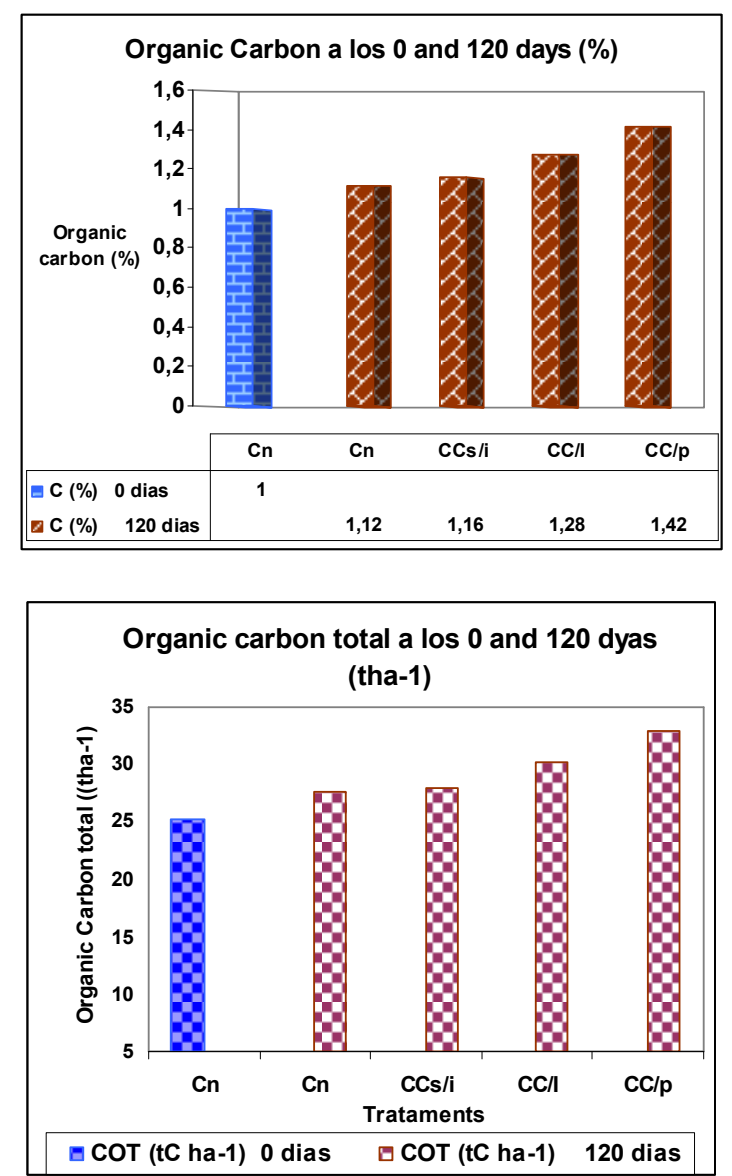

Figure 1. Organic carbon (CO, (\%) and total organic carbon (TOC, (t ha-1) in Fluvisol soil Differentiated with C. ensiformis at 0 and 120. Means with different letters in the same column differ from each other. According to the Duncan test for $p \leq 0.05$ Legend: Cn: Natural soil cover, CCs / $i$ : Canavalia cover without incorporation, $C C / i$ : Canavalia coverage incorporated, $C C /$ $p$ : permanent Canavalia coverage.

So it is shown there is an improvement in soil fertility in relation to the soil in the initial state. The natural coverage (Cn) at the beginning (0 days) and at 120 days had 
differences; these species of herbaceous plants fix C [22] according to their constitution in fallow soil and do not make contributions compared with green manures. However, the Canavalia coverage without incorporation (CCs / i) did not modify the content of the $\mathrm{CO}$ in the soil, unlike the COT; one could think of possible losses due to the management carried out, due to the exposed biomass, generating possible losses of the $\mathrm{C}$ fixed by volatilization in the form of $\mathrm{CO}_{2}$.

The CO and COT in the $\mathrm{CC} / \mathrm{i}$ and $\mathrm{CC} / \mathrm{p}$ treatments also had increases, a result that responds to the conversion of the $\mathrm{C}$ accumulated in the biomass and described previously (Table 1).

The superior results found in the $\mathrm{CC} / \mathrm{p}$ show that the natural biological cycle of the fertilizer is necessary to occur in order to favor the kidnapping of carbon and the biological fixation of the $\mathrm{N}$, since it contributes to the benefit of other processes that occur in the soil, and of course the contribution of this element is greater. The foregoing conceives that the decomposition and the humification processes to be improved are more lasting in time due to the permanence of the coverage that occurs in the soil; because it increases the $\mathrm{C}$ in a stable way, keeps the temperatures low and increases the humidity in it and also decreases it in the evapotranspiration in the soil. These results are later reflected in how they affect composition and increase in the organic fraction of the soil.

\subsection{Effect of Canavalia Ensiformis on the Increase of Carbon Present in the Humic Substances of the Soil}

The values obtained in the extractable organic $\mathrm{C}$ of the solution (soil organic carbon (COS) and carbon present in humic acid $(\mathrm{CAH})$ ) show an evolution of their values over time, with significant differences between treatments with Canavalia and the natural ground cover (Figure 2).

The COS and CAH of the $\mathrm{Cn}$ at 0 days was exceeded 120 days, but greater increases were obtained in the variables with the green manure management, mainly with Canavalia coverage incorporated and permanent. However, the same results were not presented for the CAF, which showed a decrease in all cases with respect to the initial state of the soil. In the natural coverage ( 0 days) there was a predominance of $\mathrm{C}$ present in $\mathrm{AF}$ in relation to $\mathrm{C}$ present in $\mathrm{AH}$.

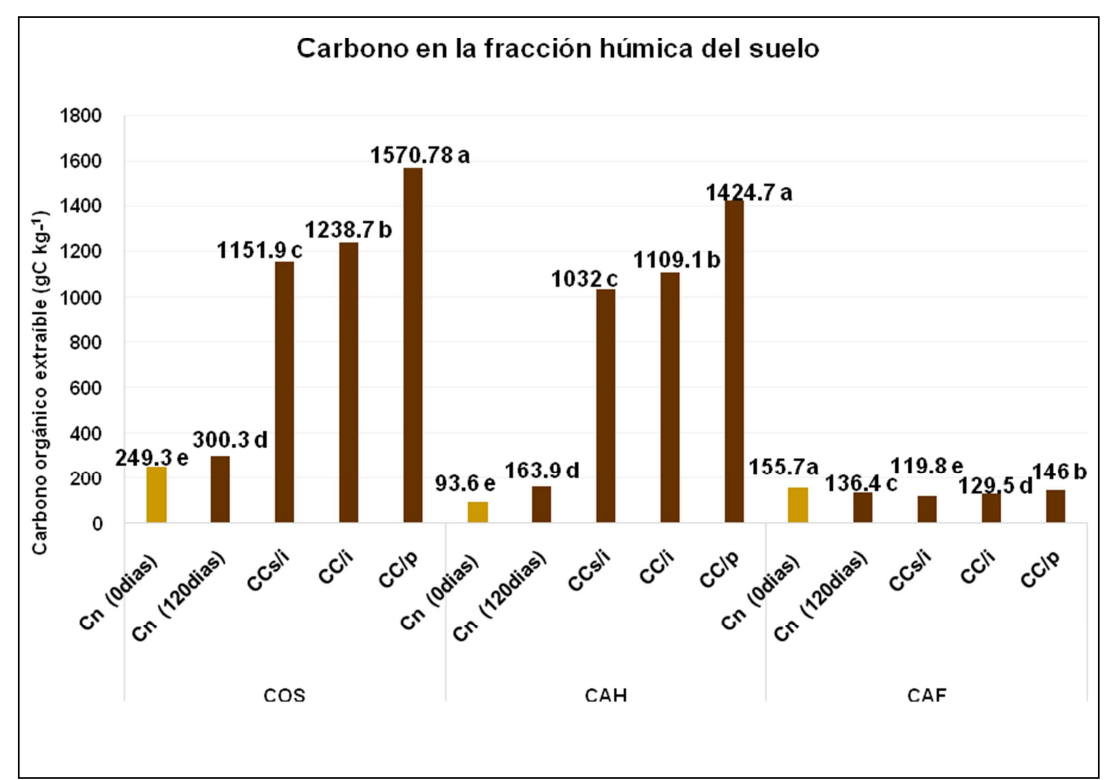

Figure 2. C content in the humic fraction of the soil at 0 and 120 days. According to Duncan's test for p $\leq 0.05$. Caption: COS (organic soluble C, (g.kg-1C): ES (x).0.353 *** CAF (organic C in fulvic acid, (g.kg-1C): ES (x).039 ***. CAH (organic C in humic acid, (g.kg-1 C) ES (x).0547 ***. Legend: Cn: natural cover, CCs/i: Canavalia coverage without incorporating, CC/i: Canavalia cover Incorporated, CC/p: Permanent Canavalia Coverage.

This predominance of AF over $\mathrm{AH}$ [17] indicates unfavorable characteristics for organic waste humus in relation to soil and $\mathrm{C}$ in fulvic acids (CAF), being an indicator of MOS condensation; also in weathered soils, these are high due to factors conditioned by continued tillage, lack of cover, environmental and territorial conditions; causing interruption in the soil humification process.

However, after 120 days there was an increase in the $\mathrm{CAH}$ in the treatment of $\mathrm{Cn}$ in favor of the humification process, assuming that there was a fixation or capture of $\mathrm{C}$ for the natural cover, and propitious modifications in the MOS and humic substances. Then, the natural cover (herbaceous plants or undesirable vegetation) [24] fixes $\mathrm{C}$, accumulates nutrients and prevents the leaching of them in smaller quantity.

The use of Canavalia in the trial, at 120 days reverses the predominance of CAF in the soil, with the prevalence of $\mathrm{CAH}$ in all treatments; shows a marked evolution and availability of carbon in humic acids $(\mathrm{CAH})$ compared to the control. The effects found are based on perception, and reveal the entry of $\mathrm{C}$ into the humic fraction of the soil and the continuous addition of it through dissimilar chemical and biological processes; then this result: it is based on an increase in the decomposition of MOS, with greater availability of $\mathrm{C}$ and also nutrients that promote chemical 
interactions with carbonaceous bases in which microorganisms participate.

This could also explain that the $\mathrm{C}$ entered in the soil solution (Table 1, Figure 1) Flows in the proper direction to stabilize the degree of condensation of aromatic structures (humification); otherwise, the reserve or predominance of $\mathrm{C}$ in AFs is restricted. In this regard, [17] the use of legumes alters the content of total organic $\mathrm{C}$, since it promotes and accumulates $\mathrm{AH}$ in the soil surface. It is also argued that an appropriate humification process occurs when the $\mathrm{CAH}$ approaches the percentage of extractable $\operatorname{COS}$ in the substance; otherwise, a process of humification would be slow when the percent of CAF is close to the hundreds of $\mathrm{C}$ of the COS [26]. This explains [27] that the values of $C$ in relation to the humic fraction are higher, more transformed, which allows validating the degree of humification of the MOS, for its characterization.

\section{Conclusions}

The Canavalia ensiformis as green manure / cover crop showed a positive effect on soil carbon stocks, a result that was higher when the legume was incorporated after the cut at 80 days and when it was left standing for 120 days.

It showed favorable conditions in the soil and improved with the use of Canavalia ensiformis as green manure / cover crop when the contribution of the carbon stock of the biomass in the soil Differentiated Fluvisol, promoted increases in carbon stocks to the soil, and improved the composition of the organic carbon present in humic substances.

\section{References}

[1] Barbero, M. F. 2010. Evolución del Carbono en suelos provenientes de monte bajo Siembra Directa del área subhúmeda templada y subtropical de Argentina. Tesis Doctoral en Ciencias Agropecuarias. Argentina.

[2] Hernández, J. A.; Cabrera, R. A.; Borges B. Y.; Vargas, B. D.; Bernal, F. A.; Morales D. M. y Ascanio G. M. O. "Degradación de los suelos Ferralíticos Rojos Lixiviados y sus indicadores de la llanura Roja de la Habana. Cultivos Tropicales Vol. 34, no 3, septiembre del 2013. ISSN 02585936. 45-51 p.

[3] Bojórquez, S. J., Castillo, P. L. A., Hernández, J. A., García, P. J. D. y Madueño, M. A. 2015. Cambios en las reservas de carbono orgánico del suelo bajo diferentes coberturas [Internet]. Cultivos Tropicales; 36 (4): 63-69p. ISSN Impreso: 0258-5936, ISSN digital: 1819-4087.

[4] Paz, P. F.; Covaleda, S.; y. Etchevers, B. J. D. 2014 Distribución del carbono orgánico del suelo en los diferentes tamaños de partículas del suelo: modelo símpele de cinética lineal. Terra Latinoamericana 32 No. 2: 127-142 p.

[5] Lehmann, J. 1998. Short - term effects of soil amendment with tree legume biomass on carbon and nitrogen in particle size separates in Central Togo. Soil Biol. Biochem. 30 (12): $1545-1552 \mathrm{p}$.

[6] Carvalho, J. E. B.; Dias, R. C. dos S.; Melo Filho, J. F. 2006.
Produção integrada $\mathrm{x}$ convencional - impacto sobre a qualidade do solo. Cruz das Almas: Embrapa Mandioca e Fruticultura Tropical, $4 \mathrm{p}$.

[7] INIA. Instituto Nacional de Investigación Agropecuaria. 2008. Jornada Abonos Verdes: Jardín De Abonos Verdes De Invierno. Uruguay. Serie Actividades de Difusión $\mathrm{N}^{\circ} 546$. Programa Nacional De Producción y sustentabilidad Ambiental.

[8] Renté, M. O.; Nápoles, G. Ma.; Pablos R. P.; Vargas, B. B. 2018. Efecto de Canavalia ensiformis (L) en propiedades físicas de un suelo Fluvisol Diferenciado en Santiago de Cuba. Cultivos Tropicales, vol. 39, no. 2, ISSN 0258-5936. ISSN digital: 1819-4087.59-64p.

[9] Corbella, R. y Fernández J. 2009. Materia Orgánica del Suelo. Cátedra de Edafología. FAZ. UNT.pdf.

[10] Melo, L. L. 2006. Análisis y caracterización de ácidos fúlvicos y su interacción con metales pesados. Tesis Lic. Química. Instituto de Ciencias Básicas e Ingeniería. Pachuca de Soto, Hidalgo. México.

[11] Garcés, N.; Hernández, A.; Caro, I.; Arteaga, M. 2009. El humus de los suelos cubanos en ecosistemas tropicales y conservados, Terra Latinoamericana, 27 (2): 85-97 p.

[12] Cotler, H.; Martínez, M. y Etchevers, J. D. 2016. Carbono orgánico en suelos agrícolas de México: Investigación políticas públicas. Terra Latinoamericana 34: 125-138 p.

[13] Hernández, A.; Pérez, J.; Bosch, D.; y Castro, N. 2015. Clasificación de los suelos de Cuba. Nueva Versión de la Clasificación Genética de los Suelos de Cuba. 2015, edit. Ediciones INCA, Mayabeque, Cuba, 2015, 93. ISBN978-9597023-77-7.

[14] Valera, V. y Carvajal, N. 2014. Economic evaluation of carbon sequestration in an area located at national park Waraira repano. Universidad Simón Bolívar. Venezuela. ANALES de la Universidad Metropolitana). Vol. 14. no. 2. 241-264p.

[15] Rügnitz, M. T.; Chacón, M. L.; Porro R. 2009. Guía para la Determinación de Carbono en Pequeñas Propiedades Rurales-1. ed. - Lima, Perú. Centro Mundial Agroflorestal (ICRAF) / Consórcio Iniciativa Amazônica (IA). World Agroforestry Centre - ICRAF. World Agroforestry Centre - ICRAF Amazon Regional Programme Avenida La Molina 1895. Apartado 1558. Lima 12, Perú. Disponible en: http://www.worldagroforestry.org. ISBN: 978-92-9059-254-9. 79 p.

[16] Walkley, A. and Black, I. A. (1934). An examination of the Degtjareff method for determining soil organic matter and preposed modification of the chromic acid tritation method. Soil Science. 37: 29-38p.

[17] Canellas, L. P. y Santos, G. A. 2005. Humosfera: tratado preliminar sobre a química das substâncias húmicas,Campos dos Goytacazes, Brasil. 309 p: il. ISBN 85-905835-1-1.

[18] García, M; Treto, E. y Álvarez, M. 2001. Comportamiento de diferentes especies de plantas para ser utilizadas como abonos verdes en las condiciones de Cuba. Cultivos Tropicales, vol. 22, no. 4, 11-16 p.

[19] Raya, P. J. C. y Aguirre, M. C. L. 2009. Composición elemental de lagunas especies de plantas silvestres mexicanas. División de Estudios de Posgrado e Investigación, Instituto Tecnológico de Roque. Revista Chapingo Serie Ciencias Forestales y del Ambiente 15 (2), México. 95-99 p. 
[20] Binder, Ulrike. 1997. Manual de leguminosas de Nicaragua. Tomo I, $1^{\text {ra }}$ ed. PASOLAC, EAGA. Estelí. Nicaragua. 528p.

[21] Loayza, T. V. 2012. Fraccionamiento químico del carbono orgánico en suelos no carbonatados de la Alpujarra Granadina. Tesis de M.Sc. Conservación, Gestión y restauración de la biodiversidad. Ecuador.

[22] Prager, M.; San Clemente, O.; Sánchez de, P. M.; Gallego J \& Ángel D. 2012. Abonos verdes: Tecnología para el manejo agroecológico de los cultivos. En Revista Agroecología, Murcia España. No. 7: 53- 62 p.

[23] González, Y. L.; Martínez, J. M. H.; Miliáns, J. G. G.; Rubido, M. G. 2009. Influencia de la alternancia de cultivos en la actividad microbiológica de un suelo tabacalero de Pinar del Río. Cuba Tabaco, ISSN-0138-7456, 10 (1): 37- 41p.
[24] Sarandón, J. S. y Flores, C. C. 2014. Agroecología: bases teóricas para el diseño y manejo de agroecosistemas sustentables. Facultad de Ciencias agrarias y Forestales. Libro. $1{ }^{\text {ra }}$ Edic. Universidad Nacional de La Plata. ISBN: 978-95034-1107-0. 291p.

[25] Cabrera, F.; Guevara, C.; Castillo, J. A.; y Chavarriaga, W. 2002. Estandarización del método de Kononova- Belchikova para la extracción, fraccionamiento, análisis y purificación de las sustancias húmicas en suelos Andisoles. Revista de Ciencias Agricola. Vol. XIX. No. I - II. Año 2002. Colombia.

[26] Arteaga, B. M; Garcés, N.; Guridiz, F.; y Pino, J. A. 2014. Una revisión sobre indicadores integradores para evaluar el impacto de las sustancias húmicas sobre el sistema suelo agua de lixiviación (I). Revista Ciencias Técnicas Agropecuarias Vol. 23, No. 3. ISSN -1010-2760, RNPS0111.Cuba. 83-88 p. 